Eur. J. Clin. Chem. Clin. Biochem.

Vol. 32,1994 , pp. $85-90$

(c) 1994 Walter de Gruyter \& Co. Berlin - New York

\title{
Comparison of an Immunoradiometric and an Immunoluminometric Assay for the Evaluation of the Tumour Associated Antigens CA 19-9 and CA 125
}

\author{
By R. M. Mader, G. G. Steger, Johanna Braun and H. Rainer \\ Onkologisches Labor der Universitätsklinik für Innere Medizin I, Wien, Austria
}

(Received March 31/November 15, 1993)

\begin{abstract}
Summary: We evaluated the levels of CA $19-9$ and CA 125 in the sera of healthy individuals, patients with nonneoplastic diseases known to produce elevated serum concentrations of CA 19-9 and CA 125, and patients with malignant tumours. The serum concentrations determined with an immunoradiometric assay (IRMA) and an immunoluminometric assay (ILMA) were compared. The accuracy was determined (as far as this is possible in the absence of reference method values), as well as the precision (intra-assay variation and inter-assay variation), using internal and external controls.
\end{abstract}

The serum concentrations were comparable in both test systems (coefficient of correlation, Kendall's Tau of CA 199: $0.88, \mathrm{p}<0.001 ; \mathrm{CA} 125: 0.87, \mathrm{p}<0.001)$. The linearity of both assays was excellent when serum samples were diluted ( $r>0.98$ in all assays tested). The intra-assay variation of CA 19-9 IRMA was less than that of CA 19-9 ILMA, and was comparable for CA 125 in both assays. The coefficients of variation of duplicates were nearly independent of the antigen concentration within the range $20-1000 \mathrm{kU} / 1$ (mean CV CA 19-9: 3.7\% and 3.9\% for IRMA and ILMA, respectively; mean CV CA 125: 3.9\% and 5.6\% for IRMA and ILMA, respectively). In the assay of external controls, the performance of the IRMAs was found to be slightly better than that of the ILMAs, but it was not satisfactory. We conclude that, with some improvements in quality control, luminescence assays are a possible alternative to isotopic assays in the clinical laboratory.

\section{Introduction}

The labelling of antibodies in immunological assays with chemiluminescent molecules is another step towards a routine laboratory free of radioisotopes $(1,2)$. A common signal generating reaction is the oxidation of aminobutylethylisoluminol (6-[N-(4-aminobutyl)- $\mathrm{N}$ ethyl] aminophthalazine $1,4(2 \mathrm{H}, 3 \mathrm{H})$ dione) to the respective carboxylic acid in alkaline solution, with the emission of light at a wavelength of $425 \mathrm{~nm}$ (3). Application of the sandwich technique, as for the immunoradiometric assay, leads to a signal proportional to the concentration of the antigen. Prerequisites for the substitution of new test methods for those already established are similar accuracy and precision. The concordance of the serum concentrations is particularly important, since tumour markers are generally interpreted over long periods of time, e.g. response during cancer chemotherapy and follow-up after surgical intervention, in order to detect a possible recurrence of a tumour (4-9).

We evaluated the levels of CA 19-9 and CA 125 in the sera of a selected collective, comprising healthy individuals, patients with non-neoplastic diseases known to produce elevated serum concentrations of CA 19-9 and CA 125 (10-12), and patients with malignant tumours. The concentrations determined with an immunoradiometric assay and an immunoluminometric assay were compared. The accuracy was determined (as far as this is possible in the absence of reference method values), as well as the precision (intra-assay variation and interassay variation), using internal and external controls.

\section{Materials and Methods}

We used the commercially available assays CA 19-9 RIA and CA 125 RIA from Centocor (Malvern, Pennsylvania, USA) and LIA- 
Tab. 1 Test procedure for the evaluation of CA 19-9 and CA 125.

\begin{tabular}{|c|c|c|}
\hline & IRMA & ILMA \\
\hline \multicolumn{3}{|l|}{ Evaluation of CA $19-9$} \\
\hline $\begin{array}{l}\text { Buffer } \\
\text { Serum sample } \\
\text { First incubation }\end{array}$ & $\begin{array}{l}0.1 \mathrm{ml} \\
0.1 \mathrm{ml} \\
3 \mathrm{~h} \text { at } \\
37^{\circ} \mathrm{C}\end{array}$ & $\begin{array}{l}0.2 \mathrm{ml} \\
0.1 \mathrm{ml} \\
\text { in a } \\
\text { water-bath }\end{array}$ \\
\hline \multicolumn{3}{|l|}{ Washing step } \\
\hline $\begin{array}{l}\text { Addition of tracer } \\
\text { Second incubation at } \\
\text { room temperature }\end{array}$ & $0.2 \mathrm{ml}$ & $\begin{array}{l}0.3 \mathrm{ml} \\
18-20 \mathrm{~h}\end{array}$ \\
\hline \multicolumn{3}{|l|}{$\begin{array}{l}\text { Washing step and measuring } \\
\text { procedure }\end{array}$} \\
\hline Upper limit of the assay: & $240 \mathrm{kU} / \mathrm{l}$ & $120 \mathrm{kU} / \mathrm{l}$ \\
\hline \multicolumn{3}{|l|}{ Evaluation of CA 125} \\
\hline $\begin{array}{l}\text { Serum sample } \\
\text { Addition of tracer } \\
\text { Incubation at room temperature } \\
\text { on an orbital shaker }\end{array}$ & $\begin{array}{l}0.1 \mathrm{ml} \\
0.1 \mathrm{ml} \\
20 \mathrm{~h}\end{array}$ & $\begin{array}{l}0.1 \mathrm{ml} \\
0.2 \mathrm{ml} \\
20 \mathrm{~h}\end{array}$ \\
\hline \multicolumn{3}{|l|}{$\begin{array}{l}\text { Washing step and measuring } \\
\text { procedure }\end{array}$} \\
\hline Upper limit of the assay: & $500 \mathrm{kU} / \mathrm{l}$ & $400 \mathrm{kU} / \mathrm{l}$ \\
\hline
\end{tabular}

mat 19-9 and LIA-mat 125 from Byk-Sangrec Diagnostica (Dietzenbach, Germany) under the conditions listed in table 1.

The activity of ${ }^{125}$ I was measured on a gamma-counter (model Crystal II, Packard, Illinois, USA). The standard curve of CA 19-9 IRMA was fitted to a cubic spline function (mass action smooth splining), and linear fitting was used for CA 125 IRMA. Chemiluminescence was measured using a CliniLumat (Berthold, Wildbad, Germany). The light signal was integrated over the 5 second interval immediately following the injection of $0.3 \mathrm{ml}$ alkaline peroxide solution and $0.3 \mathrm{ml}$ catalyst solution. The standard curves in both LIA-mat assays were adjusted with a quadratic spline function after a $\log /$ logit transformation of the signal.

Each sample was performed in duplicate and the evaluation of serum specimens was repeated if the coefficient of variation exceeded $10 \%$. Six specimens were used for quality control, three external (Bioref, Mömbris, Germany and Lyphocheck level 1 and 2, Biorad Laboratories, Hercules CA), and three internal controls (one ILMA kit control and two IRMA kit controls).

\section{Serum samples}

Serum samples $(n=184)$ were evaluated for CA $19-9$ (pancreatic cancer 40; pancreatitis 22; gastrointestinal tumours 70; alcoholic liver cirrhosis 11; several forms of hepatitis 20; sera of blood donors 21), and 188 serum samples for CA 125 (ovarian cancer 75; pancreatic cancer 40; hepatocellular carcinoma 18; alcoholic liver cirrhosis 11; several forms of hepatitis 24; sera of blood donors 20).

Serum samples were stored not longer than 4 weeks at $-20^{\circ} \mathrm{C}$ until analysis. Sera thawed once or twice were used in nearly all determinations. Stability of the antigens was tested by repeated analysis of selected samples after a storage period of 2 months.

\section{Statistics}

Correlations were generally tested by non-parametric methods (Kendall's Tau) and, when applicable, by linear regression (e.g. in
dilution experiments).

\section{Results}

Concordance of CA 19-9 and CA 125 concentrations in serum

With some exceptions, the concentrations of CA 19-9 (fig. 1) and CA 125 (fig. 2) in serum were comparable in both test systems (coefficient of correlation, Kendall's Tau, CA 19-9: 0.88, p <0.001; CA 125: 0.87, $\mathrm{p}<0.001)$.

The following equations can be used for the conversion of the test results from one assay to the other:

CA 19-9: value ILMA $=1.005 \times$ value $I R M A+9.0$

(standard error of the slope: 0.010, intercept: 8.6; $\mathrm{n}=184$ )

CA 125: value ILMA $=0.999 \times$ value IRMA -5.5 (standard error of the slope: 0.007, intercept: 8.0; $\mathrm{n}=188$ )

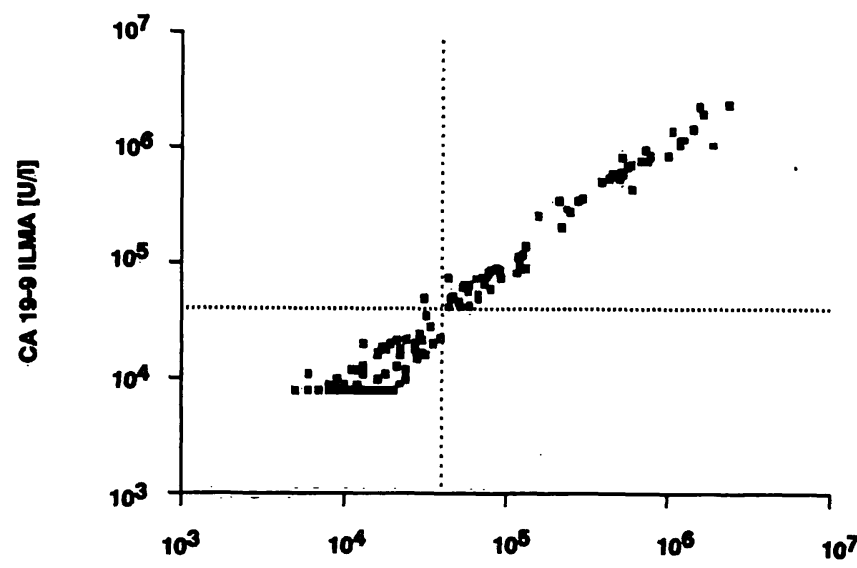

Fig. 1 Correlation of CA $19-9$ values for 184 serum samples. Dotted lines indicate a concentration of $40 \mathrm{kU} / \mathrm{h}$.

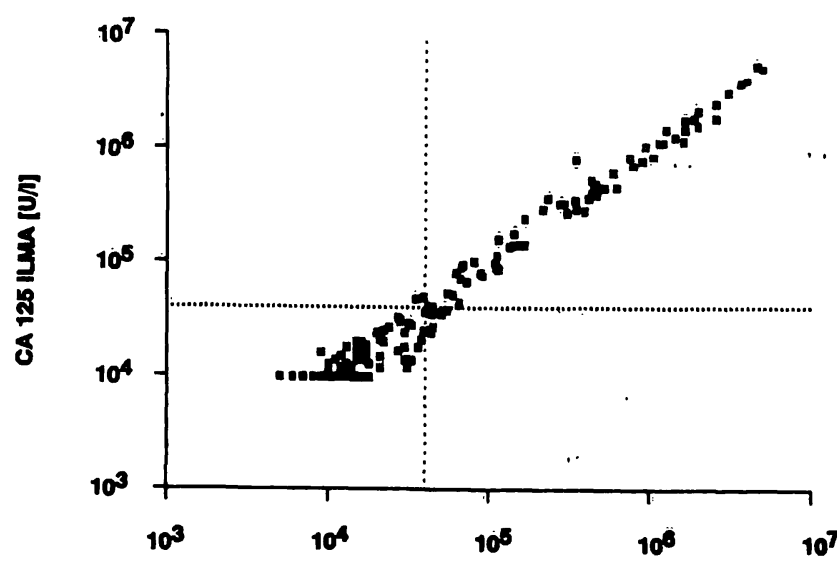

Fig. 2 Correlation of CA 125 values for 188 serum samples. Dotted lines indicate a concentration of $40 \mathrm{kU} / \mathrm{l}$. 
This correlation varied when the results were subdivided according to the diagnosis. For CA 19-9, the coefficients of correlation were higher than the overall correlation in pancreatic carcinoma $(r=0.96)$, and were equal in gastrointestinal cancer $(r=0.88)$. The concordance of the concentrations in serum was lower in patients with hepatitis $(r=0.82)$, liver cirrhosis $(r=0.80)$, and pancreatitis $(0.78)$, and differed substantially in normal subjects $(r=0.47)$. For CA 125 , a correlation significantly below the overall value was observed in healthy individuals only $(r=0.56)$.

The detection limits of the assays (calculated as the lowest value distinguishable from the zero calibrator +3 S.D.) were $1.5 \mathrm{kU} / 1$ for both ILMAs, and $2 \mathrm{kU} / 1$ for CA 19-9 IRMA and $3 \mathrm{kU} / \mathrm{l}$ for CA 125 IRMA.

No data concerning the test specificity are reported, since lipaemic or haemolytic sera were not included in this evaluation.

\section{Quality control of CA 19-9}

\section{Intra:assay variation}

The intra-assay variation was estimated from the reproducibility of the examined controls $(n=8)$, as well as from the mean coefficient of variation of the patient samples (tab. 2). An unacceptably high coefficient of variation was observed when assaying the Bioref control with CA 19-9 ILMA (CV = 17\%).

In serum samples, the reproducibility of the IRMA and the ILMA was nearly independent of the antigen level at concentrations in the range $20-1000 \mathrm{kU} / \mathrm{l}$ (tab. 3).

\section{Accuracy and precision of the internal control samples}

When evaluated in the respective assay, the internal controls from the manufacturer were slightly higher than indicated in the ILMA (mean deviation from target con-

Tab. 2 Intra-assay variation of CA 19-9 using different control specimens $(n=8)$.

\begin{tabular}{|c|c|c|c|c|}
\hline & \multicolumn{2}{|l|}{ IRMA } & \multicolumn{2}{|l|}{ ILMA } \\
\hline & $\begin{array}{l}\text { CA 19-9 } \\
{[\mathrm{kU} / \mathrm{l}]}\end{array}$ & $\begin{array}{l}\text { CV } \\
{[\%)}\end{array}$ & $\begin{array}{l}\text { CA 19-9. } \\
{[\mathrm{kU} / \mathrm{l}]}\end{array}$ & $\begin{array}{l}\mathrm{CV} \\
{[\%]}\end{array}$ \\
\hline ILMA-control & - & n.e. & 77.5 & 7.7 \\
\hline Lyphocheck level 1 & 23.2 & 6.3 & 40.1 & 6.2 \\
\hline Lyphocheck level 2 & 122 & 5.7 & 73.9 & 7.3 \\
\hline Bioref & 48 & 4.7 & 29.9 & 17 \\
\hline IRMA-control low & 56.7 & 2.5 & 75.8 & 11 \\
\hline IRMA-control high & 113 & 4.8 & - & n.e. \\
\hline Serum samples & - & 5.8 & - & 6.5 \\
\hline
\end{tabular}

n.e. $=$ not evaluated
Tab. 3 Precision profile of CA 19-9 IRMA, CA 19-9 ILMA, CA 125 IRMA, and CA 125 ILMA (data calculated from serum samples from patients).

\begin{tabular}{llllll}
\hline \multirow{2}{*}{$\begin{array}{l}\text { Concentrations } \\
{[\mathrm{kU} / 1]}\end{array}$} & \multicolumn{3}{l}{ Coefficient of variation [\%] } \\
\cline { 2 - 3 } & \multicolumn{2}{l}{ CA 19-9 } & & CA 125 \\
\cline { 2 - 3 } \cline { 5 - 6 } & IRMA & ILMA & & IRMA & ILMA \\
\hline-10 & 12.4 & 12.7 & 9.4 & 12.0 \\
$11-20$ & 4.3 & 6.8 & & 4.8 & 8.4 \\
$21-30$ & 3.1 & 3.6 & & 3.5 & 4.8 \\
$31-50$ & 3.3 & 4.0 & & 4.0 & 4.8 \\
$51-70$ & 3.3 & 4.3 & & 2.5 & 4.5 \\
$71-100$ & 3.4 & 3.4 & 4.9 & 5.6 \\
$101-250$ & 4.5 & 3.7 & 5.0 & 7.4 \\
$251-1000$ & 4.1 & 4.3 & 3.4 & 6.4 \\
\hline
\end{tabular}

centration: $+1.3 \%, \mathrm{CV}=3.7 \% ; \mathrm{n}=8)$, whereas lower means were observed with the IRMA (internal control low, mean deviation from target concentration: $-3.6 \%$, $\mathrm{CV}=6.2 \%$; internal standard high, mean deviation from target concentration: $-3.2 \%, \mathrm{CV}=6.3 \% ; \mathrm{n}=8$ ).

The linearity of the assays was checked by diluting serum specimens of high antigen concentrations (coefficient of correlation $>0.98$ in both assays).

\section{Inter-assay variation}

To simulate the situation in a routine laboratory, interassay variation was determined by using five different lots (tab. 4).

Tab. 4 Accuracy and precision of the CA 19-9 controls $(n=8)$.

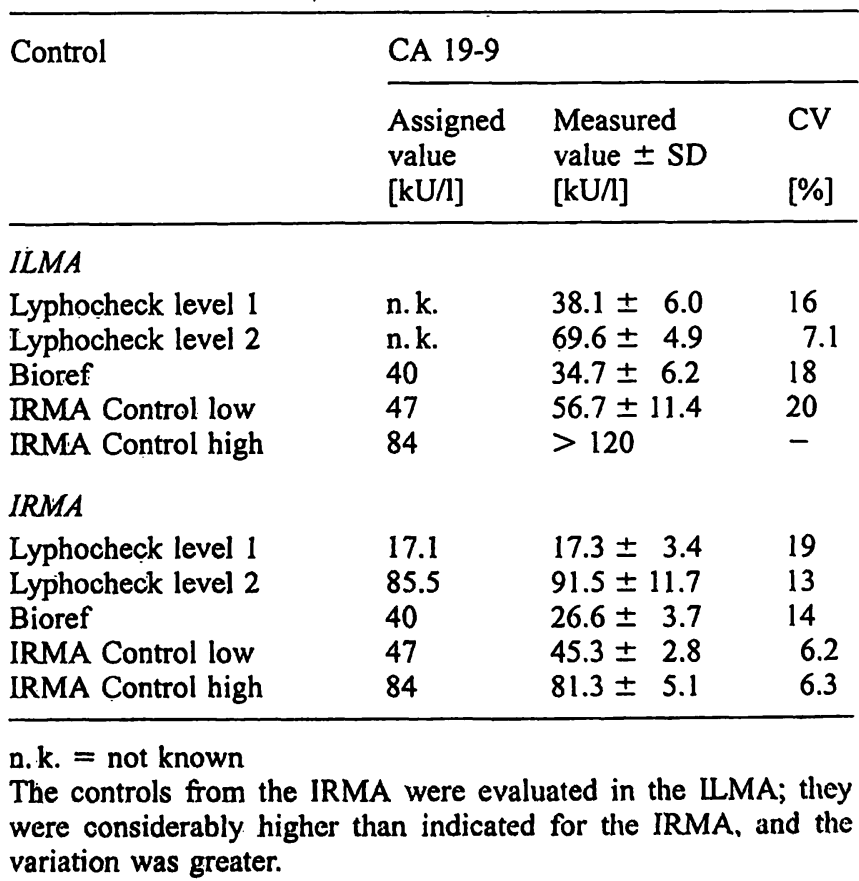

Eur. J. Clin. Chem. Clin. Biochem. / Vol. 32, 1994 / No. 2 
Lyphocheck control specimens, analysed without reference values for CA 19-9 ILMA, showed a lot-to-lot reproducibility of $<20 \%(n=8)$ with variations similar to those found for the IRMA (CV < 19\%; $n=8)$. For the Bioref sample, reference ranges below the concentration of $40 \mathrm{kU} / \mathrm{l}$ stated by the manufacturer were established (ILMA: $34.7 \pm 6.2 \mathrm{kU} / \mathrm{l} ;$ IRMA: $26.6 \pm 3.7$ $\mathrm{kU} / \mathrm{l} ; \mathrm{n}=8)$.

\section{Quality control of CA 125}

\section{Intra-assay variation}

The intra-assay variation was estimated from the reproducibility of the duplicates from patient samples as well as from the controls (tab. $5 ; n=8$ ) and was found to be generally $<8 \%$ with one exception for each assay.

As for CA 19-9, the concentrations of CA 125 in serum were subdivided into ranges to analyse the precision profile (tab: 3). The reproducibility of CA 125 IRMA and CA 125 ILMA was found to be nearly independent of the serum levels at concentrations between 20 and $1000 \mathrm{kU} / \mathrm{l}$ (tab. 3).

\section{Accuracy and precision of the internal control samples}

The internal controls from the manufacturer evaluated in the respective assay were $2.3 \%$ below the target value in the ILMA (CV $=9.6 \% ; n=8)$ and $2.8 \%$ higher in the IRMA (CV $=7 \%$, IRMA control low). The high IRMA control matched perfectly the target value of 110 $\mathrm{kU} / \mathrm{l}(\mathrm{CV}=5.3 \%)$.

The linearity of both assays was checked by diluting serum specimens of high antigen concentrations (coefficient of correlation $>0.99$ in both assays).

Tab. 5 Intra-assay variation of CA 125 using different control specimens $(n=8)$.

\begin{tabular}{|c|c|c|c|c|}
\hline & \multicolumn{2}{|l|}{ IRMA } & \multicolumn{2}{|l|}{ ILMA } \\
\hline & $\begin{array}{l}\text { CA } 125 \\
{[\mathrm{kU} / \mathrm{l}]}\end{array}$ & $\begin{array}{l}\mathrm{CV} \\
{[\%]}\end{array}$ & $\begin{array}{l}\text { CA } 125 \\
{[\mathrm{kU} / \mathrm{l}]}\end{array}$ & $\begin{array}{l}\mathrm{CV} \\
{[\%]}\end{array}$ \\
\hline ILMA Control & - & n.e. & 114 & 7.0 \\
\hline Lyphocheck level 1 & 30.0 & 6.0 & 40.8 & 12 \\
\hline Lyphocheck level 2 & 185 & 6.7 & 74.2 & 5.6 \\
\hline Bioref & 19.5 & 12.2 & 36.9 & 7.8 \\
\hline IRMA Control low & 51.8 & 4.9 & 59.8 & 7.0 \\
\hline IRMA Control high & 114 & 4.5 & 121 & 4.8 \\
\hline Serum samples & - & 5.2 & - & 7.2 \\
\hline
\end{tabular}

n. e. $=$ not evaluated
Tab. 6 Accuracy and precision of the CA 125 controls $(n=8)$.

\begin{tabular}{|c|c|c|c|}
\hline \multirow[t]{2}{*}{ Control } & \multicolumn{3}{|l|}{ CA 125} \\
\hline & $\begin{array}{l}\text { Assigned } \\
\text { value } \\
{[\mathrm{kU} / \mathrm{l}]}\end{array}$ & $\begin{array}{l}\text { Measured } \\
\text { value } \pm \mathrm{SD} \\
{[\mathrm{kU} / \mathrm{l}]}\end{array}$ & $\begin{array}{l}\mathrm{CV} \\
{[\%]}\end{array}$ \\
\hline$I L M A$ & \multicolumn{2}{|c|}{.1} & \\
\hline $\begin{array}{l}\text { Lyphocheck level } 1 \\
\text { Lyphocheck level } 2 \\
\text { Bioref } \\
\text { IRMA Control low } \\
\text { IRMA Control high }\end{array}$ & $\begin{array}{l}46.8 \\
91.1 \\
50 \\
53 \\
110\end{array}$ & $\begin{array}{r}38.5 \pm 4.6 \\
66.7 \pm 7.0 \\
34.2 \pm 3.5 \\
54.0 \pm 7.0 \\
107 \pm 18.7\end{array}$ & $\begin{array}{l}12 \\
11 \\
10 \\
13 \\
17\end{array}$ \\
\hline \multicolumn{4}{|l|}{$I R M A$} \\
\hline $\begin{array}{l}\text { Lyphocheck level } 1 \\
\text { Lyphocheck level } 2 \\
\text { Bioref } \\
\text { IRMA Control low } \\
\text { IRMA Control high }\end{array}$ & $\begin{array}{r}28.5 \\
154 \\
50 \\
53 \\
110\end{array}$ & $\begin{array}{r}32.1 \pm 3.0 \\
187 \pm 20.4 \\
26.5 \pm 4.6 \\
54.4 \pm 3.8 \\
110 \pm 5.8\end{array}$ & $\begin{array}{l}9.4 \\
11 \\
17 \\
7.0 \\
5.3\end{array}$ \\
\hline
\end{tabular}

\section{Inter-assay variation}

As for CA 19-9, the investigation was performed with five different kit lots (tab. 6).

Problems were encountered with regard to the accuracy of the Lyphocheck controls, as none of the assays matched the target concentrations, whereas the inter-assay reproducibility was acceptable in both assays (CV $<17 \%, \mathrm{n}=8)$. CA 125 ILMA performed well with the Bioref control $(\mathrm{CV}=10 \%)$.

\section{Discussion}

We report a comparison of two immunoluminometric assays for CA 19-9 and CA 125 with the established immunoradiometric assays, in which we determined more than 180 serum samples under routine laboratory conditions. We used five different lots for the determination of the concentrations of CA 125 and CA 19-9 in serum. Therefore, the inter-assay variation not only includes the between-assay precision of the laboratory, but also the manufacturer's ability to produce tests with high reproducibility.

These data are subject to the limitation that only 8 experiments were performed for the calculation of the quality control. Twenty evaluations would be preferable, but this number was not possible for financial and technical reasons.

In 1990, an evaluation of the chemiluminescence immunoassays CA 15-3, CA 125 and CA 19-9 (13) reported a $\mathrm{CV}=5-8 \%$ (intra-assay precision) and a $\mathrm{CV}$ $=5-17 \%$ (inter-assay precision). This study focused on the precision and accuracy of reference samples and reported only a few results concerning serum samples 
from patients. The study by Plebani and co-workers (14) reported an excellent inter-assay variation of the new method. The correlation in their collective was slightly better for CA $125(r=0.99)$ than for CA 19-9 $(r=0.97)$, but they used parametric test methods for the statistical evaluation.

Other studies investigated the diagnostic value of $\mathrm{CA}$ 125 by comparing enzyme-immunoassays with radioimmunoassays, including more than 100 serum samples $(15,16)$. In all cases, the coefficient of correlation was better than $r=0.85$, but the slope was found to differ considerably from 1 for the EIA from Abbott relative to the IRMA from Centocor (slope $=0.75$ in the study of Pittaway, (17)) with consequences for the sensitivity of the enzyme-immunoassay, as well as for the conversion of the tumour marker concentrations from one system to another. Therefore, the long term interpretation requires concordant results in different assays. With some exceptions for the low serum concentrations (values $<30$ $k U / 1)$, we obtained comparable results with both assay systems.

The fitting of the standard curve with a spline function after $\log$ /logit transformation excludes the zero calibrator of the standard curve. Using the next calibrator as the lowest evaluable antigen concentration is problematic, in that lower concentrations cannot be reported as the authentic value. In the clinical use of tumour markers this is generally not a problem, but could become a statistical one. In correlation analyses, small deviations in the lowest concentration range do certainly not falsify sample calculations based on more than 180 samples, but are misleading in the healthy sample $(r=0.47$ and 0.56 for CA 19-9 and CA 125 , respectively).

The aim of the study was to compare the performance of the assays and particularly the concordance of the serum concentrations. Thus, we did a cross sectional investigation in order to evaluate the maximal number of serum specimens instead of a serial follow-up study

\section{References}

1. Schroeder, H. R., Boguslaski, R. C., Carrico, R. J. \& Buckler, R. T. (1978) Monitoring specific protein-binding reactions with chemiluminescence. Meth. Enzymol. 57, 424-445.

2. Whitehead, T. P., Kricka, L. J., Carter, T. J. M. \& Thorpe, G. H. J. (1979) Analytical luminescence: Its potential in the clinical laboratory. Clin. Chem. 25, 1531-1546.

3. Schroeder, H. R. \& Yeager, F. M. (1978) Chemiluminescence yields and detection limits of some isoluminol derivatives in various oxidation systems. Anal. Chem. 50, 1114-1120.

4. Bast, R. C., Klug, T. L., St. John, E., Jenison, E., Niloff, J. M., Lazarus, H., Berkowitz, R. S., Leavitt, T., Griffiths, T., Parker, L., Zurawski, V. R. \& Knapp, R. C. (1983) A radioimmunoassay using a monoclonal antibody to monitor the course of epithelial ovarian cancer. N. Engl. J. Med. 309, 883-887. dealing repeatedly with the same serum matrix. The concordance of the serum concentrations was in contradiction to some results obtained with the external controls. While the internal controls were correct in all assays, problems were encountered in evaluating the accuracy (as far as this is possible in the absence of reference method values) of the control sera from Bioref and Lyphocheck.

When this study started, no target values were indicated for Lyphocheck control sera in the CA 19-9 ILMA. It was therefore possible to determine only the inter-assay variation, which was acceptable at a value of $40 \mathrm{kU} / \mathrm{l}$ and good at a value of $70 \mathrm{kU} / \mathrm{l}$, considering that five different lots were used for the ILMA. Some problems arise from the poor chemical definition of the controls; this concerns the structure of the antigens themselves, as well as the poorly defined serum matrix. The Bioref control sample is a pooled serum matrix, but can be used only after establishing appropriate reference intervals after a large number of runs. Considerable deviations from the target concentrations were observed in our study. A priority in the field of human tumour markers remains therefore the production of standardised control sera. This would allow the critical examination of small deviations from the target values, in order to evaluate the inter-assay variation as well as the lot-to-lot variation correctly.

The handling of the assays was nearly identical. A difference inherent in the luminescence assay is that the isoluminol molecule bound to the antibody is consumed during the chemiluminescence reaction rendering repeated measurements impossible.

We conclude that the immunoluminometric assay for CA 125 and CA 19-9 with additional quality control from the manufacturer could be an alternative to the immunoradiometric assay, because the serum values correlate well. At the moment, the performance of the radioimmunoassays is better.
5. Bast R. C., Klug, T. L., Schaetzl, E., Lavin, P., Niloff, J. M., Greber, T. F., Zurawski, V. R. \& Knapp, R. C. (1984) Monitoring human ovarian carcinoma with a combination of CA 125 , CA 19-9 and carcinoembryonic antigen. Am J. Obstet. Gynecol. 149, 553-559.

6. Briaschi, P. A., Bischof, P., Rapin, C., De Roten, M., Irion, O. \& Krauer, F. (1985) Longitudinal study of CEA and CA 125 in ovarian cancer. Gynecol. Oncol. 21, 1-6.

7. Niloff, J. M., Bast, R. C., Schaetzl, E. M. \& Knapp, R. C. (1985) Predictive value of CA 125 antigen levels in secondlook procedures for ovarian cancer. Am. J. Obstet. Gynecol. 151, 981-986.

8. Staab, H. J., Brümmendorf, T., Hornung, A., Anderer, F. A. \& Kieninger, G. (1.985) The clinical validity of circulating tumor- 
associated antigens CEA and CA $19-9$ in primary diagnosis and follow-up of patients with gastrointestinal malignancies. Klin. Wochenschr. 63, 106-115.

9. Glenn, J., Steinberg, W. M., Kurtzman, S. H., Steinberg, S. M. \& Sindelar, W. F. (1988) Evaluation of the utility of a radioimmunoassay for serum CA 19-9 levels in patients before and after treatment of carcinoma of the pancreas. J. Clin. Oncol. 6, 462-468.

10. Ruibal, A., Encabo, G., Martinez-Miralles, E.., Murcia, C., Capdevilla, J. A., Salgado, A. \& Martinez-Vasquez, J. M. (1984) CA 125 seric levels in non malignant pathologies. Bull. Cancer 71, 145-148.

11. Encabo, G. \& Ruibal, A. (1986) Seric CA 19-9 levels in patients with non tumoral pathologies. Bull. Cancer 73 , 256-259.

12. Harmenberg, U., Wahren, B. \& Wiechel, K. L. (1988) Tumor markers carbohydrate antigens CA $19-9$ and CA-50 and carcinoembryonic antigen in pancreatic cancer and benign diseases of the pancreatobiliary tract. Cancer Res. 48, 1985-1988.

13. Zucchelli, G. C., Pilo, A., Reum, L., Chiesa, M. R., Clerico, A. \& Ferdeghini, M. (1990) A new chemiluminescence immunoassay for CA 15-3, CA 125, CA 19-9: Evaluation us- ing QC sera assayed in an interlaboratory survey. J. Nucl. Med. Allied Sci. 34, 222-228.

14. Plebani, M., Faggian, D., Masiero, M. \& Burlina, A. (1990) CA 19-9 and CA 125 determination by immunoluminometric assay. J. Clin. Chem. Clin. Biochem. 28, 919-921.

15. Fisken, J., Leonard, R. C. \& Roulsten, J. E. (1989) Immunoassay of CA 125 in ovarian cancer: A comparison of three assays for use in diagnosis and monitoring. Disease Markers 7, 61-67.

16. Fasquelle, D., Villemain, D., Meffre, G. \& Agnnius=-Delord, C. (1988) Dosage du marqueur tumoral CA 125 dans les cancers de l'ovaire: Comparaison des methodes immunoenzymatique et immunoradiometrique. Pathol. Biol. 36, 225-229.

17. Pittaway, D. E. (1988) Correlation of an enzyme immunoassay with the radioimmunoassay for CA-125. Am. J. Obstet. Gynecol. $158,62-64$.

Dr. Robert M. Mader

Department of Internal Medicine I

Division of Oncology

Währinger Gürtel 18-20

A-1090 Vienna

Austria 